\title{
Artificial Metalloprotease Based on Co(III)oxacyclen-Aldehyde Conjugate ${ }^{\dagger}$
}

\author{
Min Gyum Kim, Hye Mi Kim, and Junghun Suh ${ }^{*}$ \\ Department of Chemistry, Seoul National University, Seoul 151-747, Korea. "E-mail: jhsuh@snu.ac.kr \\ Received February 8, 2011, Accepted February 23, 2011
}

Key Words : Co(III)oxacyclen, Artificial protease, Artificial metalloprotease, Artificial enzyme, Proteolysis

Proteases share about $60 \%$ of the total worldwide sale of industrial enzymes. ${ }^{1}$ Most of the industrial proteases have broad substrate selectivity, hydrolyzing a variety of protein substrates they encounter. In view of thermal and chemical instabilities of natural enzymes, synthesis of protease-like catalysts (artificial proteases) with broad substrate selectivity and high thermal and chemical stabilities is important.

The $\mathrm{Cu}$ (II) and $\mathrm{Co}$ (III) complexes of 1,4,7,10-tetraazadodecane (cyclen) have been often exploited as the catalytic centers for artificial proteases. ${ }^{2-11}$ Proteolytic activity of the $\mathrm{Cu}$ (II) complex ( $\mathrm{Cu}$ (II)cyclen) of cyclen was greatly enhanced on attachment to polystyrene backbone apparently due to the hydrophobic microenvironment. ${ }^{3}$ When the aldehyde group was positioned in proximity of the $\mathrm{Cu}$ (II)cyclen anchored on crosslinked polystyrene, heterogeneous artificial proteases with high proteolytic activity and broad substrate selectivity were produced. ${ }^{8}$ This was due to reversible imine formation between the aldehyde group of the artificial protease and the ammonium ion exposed on the surface of the substrate protein. A later study disclosed that the $\mathrm{Cu}(\mathrm{II})$ complex $(\mathrm{Cu}$ (II)oxacyclen) of 1-oxo-4,7,10-triazadodecane (oxacyclen) had a much higher proteolytic activity compared with $\mathrm{Cu}$ (II) cyclen owing to the enhanced Lewis acidity of the $\mathrm{Cu}$ (II) center. ${ }^{12}$ Introduction of the aldehyde group in proximity to $\mathrm{Cu}(\mathrm{II})$ oxacyclen produced homogeneous artificial proteases with high proteolytic activity, broad substrate selectivity, and high thermal and chemical stabilities. ${ }^{13}$ The activity of the homogeneous artificial protease based on the $\mathrm{Cu}$ (II)oxacyclenaldehyde conjugate was comparable to the heterogeneous artificial protease based on the $\mathrm{Cu}(\mathrm{II})$ cyclen-aldehyde-polystyrene conjugate.

Artificial proteases based on the exchange-inert ${ }^{14} \mathrm{Co}$ (III) complexes have advantages compared with those on the exchange-labile $\mathrm{Cu}$ (II) complexes in practical applications.

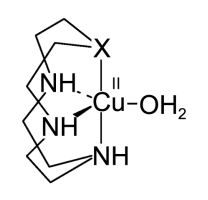

$\mathrm{Cu}(\mathrm{II})$ cyclen: $\mathrm{X}=\mathrm{NH}$ Cu(II)oxacyclen: $\mathrm{X}=\mathrm{O}$

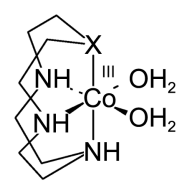

Co(III)cyclen: $\mathrm{X}=\mathrm{NH}$ Co(III)oxacyclen: $\mathrm{X}=\mathrm{O}$
${ }^{\top}$ This paper is dedicated to Professor Eun Lee on the occasion of his honourable retirement.
Abstraction of the metal centers from the catalysts by metalbinding substances present in the reaction mixture may limit the lifetime of the catalyst. It was reported that the proteolytic activity of the $\mathrm{Co}$ (III) complex (Co(III)oxacyclen) of oxacyclen is much higher than that of the $\mathrm{Co}$ (III) complex (Co(III) cyclen) of cyclen due to the enhanced Lewis acidity of the Co(III) center. ${ }^{15}$ In the present study, a homogeneous artificial protease based on the $\mathrm{Co}$ (III)oxacyclen-aldehyde conjugate was synthesized and its proteolytic activity was characterized.

As the aldehyde-containing artificial protease, $\operatorname{Co}(\mathrm{III}) \mathbf{A}$, the Co(III) complex of 4-((4-(2-methyl-butylamino)-6-(3-(1-oxa4,7,10-triaza-cyclododec-7-yl)-propylami-no)-1,3,5-triazin-2ylamino)-methyl)-benzaldehyde (A), was synthesized. As the control of Co(III)A, the Co(III) complex (Co(III)B) of $N$-benzyl$N$ '-(2-methyl-butyl)- $N$ "-(2-(1-oxa-4,7,10-triaza-cyclododec-7yl)-ethyl)-1,3,5-triazine-2,4,6-triamine (B), was prepared. As the protein substrates, bovine serum albumin (Alb), bovine serum $\gamma$-globulin (Glo), horse heart myoglobin (Myo), and chicken egg white lysozyme (Lys) were employed. Myoglobin is oxidized to metmyoglobin in the presence of oxygen and the myoglobin used in the present study was also in the met form as checked by its visible spectrum. ${ }^{16}$

The rates for disappearance of the protein substrate during the reaction with $\mathrm{Co}(\mathrm{III}) \mathbf{A}$ or $\mathrm{Co}$ (III)B was measured by sodium dodecyl sulfate polyacrylamide gel electrophoresis, ${ }^{17}$ as described previously. $3,6,8,12,13,15$ The pseudo-first-order kinetic constant $\left(k_{0}\right)$ thus obtained is related to the cleavage of the substrate protein molecule itself and does not provide information on further fragmentation of the initial cleavage products. Glo has two subunits with distinctly different molecular weights (25 and $50 \mathrm{kDa}$ ). Since the density of the electrophoretic band of the light chain was weak, the kinetic

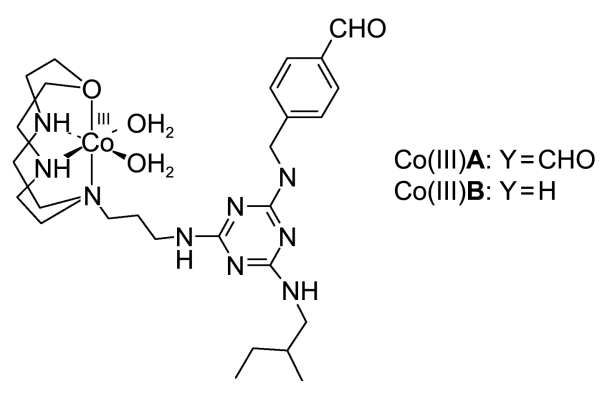


data were collected only for the degradation of the heavy chain.

The $k_{0}$ values were measured for each substrate in the presence of $\mathrm{Co}$ (III)A at various $\mathrm{pH}$ 's and at fixed $C_{0}$ (initially added catalyst concentration) and $S_{0}$ (initially added substrate concentration) under the conditions of $C_{0}(0.2 \mathrm{mM})>S_{0}$ $(3-10 \mu \mathrm{M})$ to identify the optimum $\mathrm{pH}$. The kinetic data were obtained up to $\mathrm{pH} 9.5$ to avoid complications due to background alkaline degradation of proteins at higher $\mathrm{pH}$ 's. At the optimum $\mathrm{pH}$ thus selected, the $k_{0}$ values were measured at various $C_{0}$ concentrations under the conditions of $C_{0} \gg>$ $S_{0}$. As shown by the dependence of $k_{0}$ on $C_{0}$ (Figs. 1-4), saturation kinetic behavior was observed for the cleavage of the protein substrates by $\operatorname{Co}(\mathrm{III}) \mathbf{A}$ and $\mathrm{Co}(\mathrm{III}) \mathbf{B}$.

Kinetic data for the cleavage of the protein substrates by Co(III)A or Co(III)B were analyzed in terms of MichaelisMenten scheme (eq. 1). Under the conditions of $C_{0}>>[C S]$, pseudo-first-order kinetic behavior is expected with $k_{0}$ being derived as eqs. 2-4. Here, $[C S]$ is the steady state concentration of $C S$. The dependence of $k_{0}$ on $C_{0}$ was analyzed to estimate $k_{\text {cat }}, K_{\mathrm{m}}$, and their standard deviations. The values of $k_{\text {cat }}$ and $K_{\mathrm{m}}$ thus estimated for the cleavage of the protein substrates by $\mathrm{Co}(\mathrm{III}) \mathbf{A}$ or $\mathrm{Co}(\mathrm{III}) \mathbf{B}$ are summarized in Table 1.

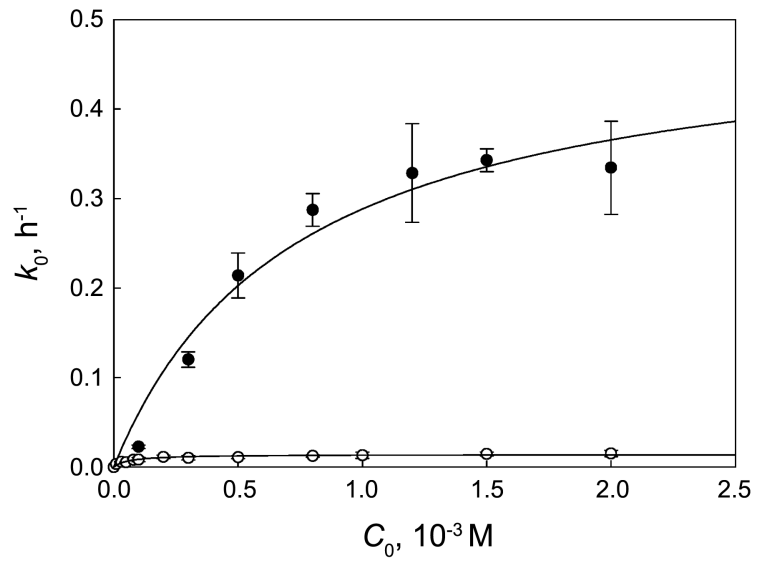

Figure 1. Plot of $k_{0}$ against $C_{0}$ for cleavage of Alb $(3.0 \mu \mathrm{M})$ by $\mathrm{Co}(\mathrm{III}) \mathbf{A}$ (filled circle) or $\mathrm{Co}(\mathrm{III}) \mathbf{B}$ (open circle) at $\mathrm{pH} 9.5$ and $50{ }^{\circ} \mathrm{C}$.

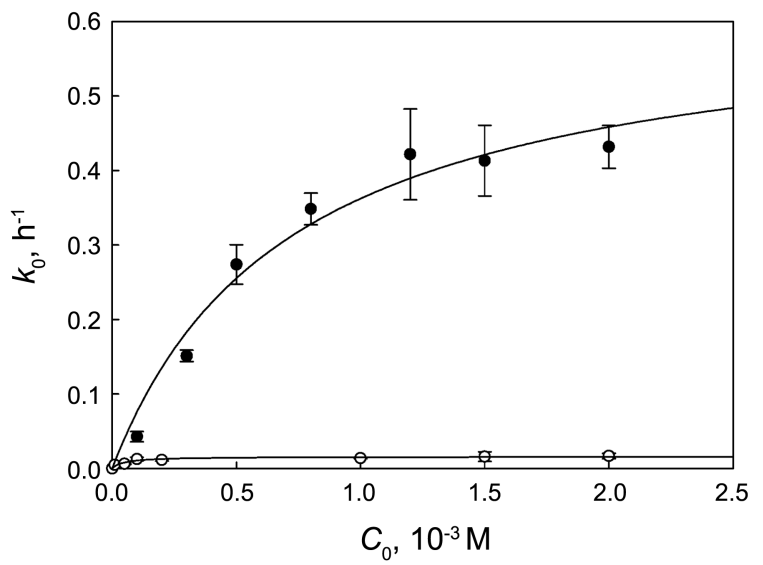

Figure 2. Plot of $k_{0}$ against $C_{0}$ for cleavage of Glo $(2.7 \mu \mathrm{M})$ by Co(III)A (filled circle) or Co(III)B (open circle) at $\mathrm{pH} 9.5$ and $50{ }^{\circ} \mathrm{C}$.

$$
\begin{aligned}
& C+S \underset{k_{-1}}{\stackrel{k_{1}}{\rightleftarrows}} C S \stackrel{k_{2}}{\longrightarrow} C+P \\
& k_{\mathrm{o}}=k_{\mathrm{cat}} C_{0} /\left(K_{\mathrm{m}}+C_{0}\right) \\
& k_{\mathrm{cat}}=k_{2} \\
& K_{\mathrm{m}}=\left(k_{-1}+k_{2}\right) / k_{1}=[C][S] /[C S]
\end{aligned}
$$

The results summarized in Figs. 1-4 indicate that the proteolytic activity of the $\mathrm{Co}$ (III) center is considerably en-

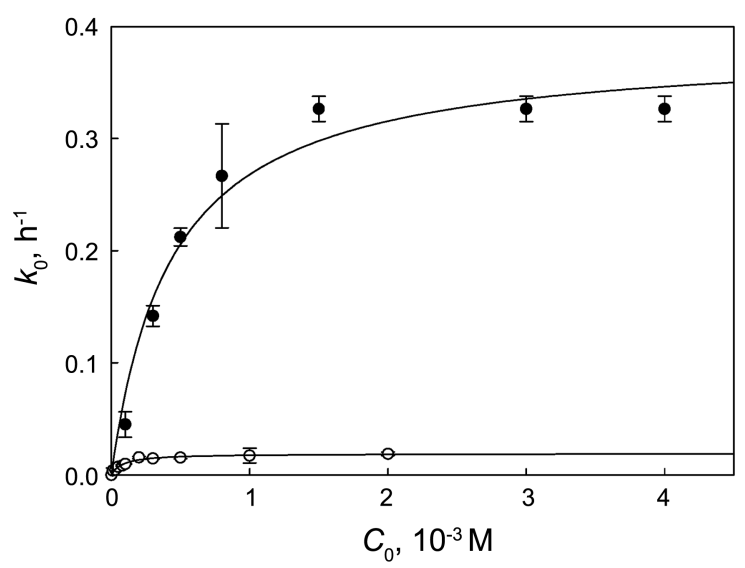

Figure 3. Plot of $k_{0}$ against $C_{0}$ for cleavage of Myo $(10 \mu \mathrm{M})$ by Co(III)A (filled circle) or Co(III)B (open circle) at $\mathrm{pH} 8.0$ and $50{ }^{\circ} \mathrm{C}$.

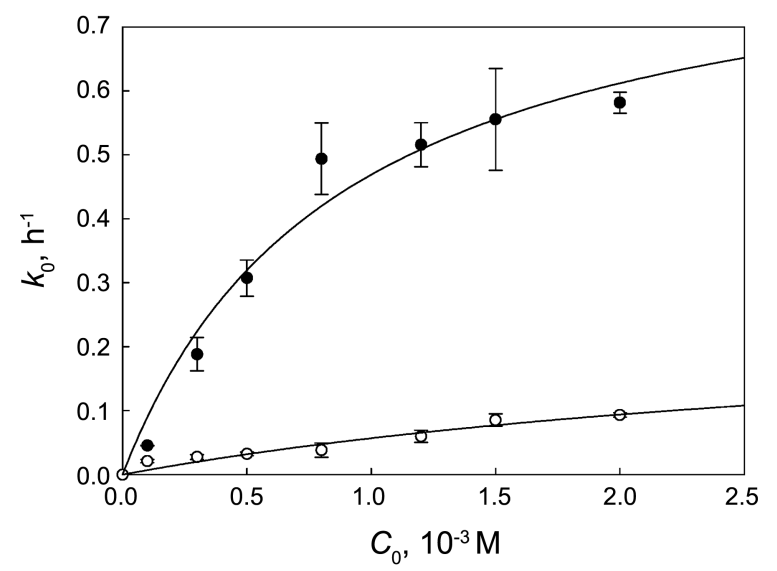

Figure 4. Plot of $k_{0}$ against $C_{0}$ for cleavage of Lys $(7.0 \mu \mathrm{M})$ by Co(III)A (filled circle) or Co(III)B (open circle) at pH 9.5 and $50^{\circ} \mathrm{C}$.

Table 1. Values of kinetic parameters for the cleavage of various protein substrates by $\mathrm{Co}(\mathrm{III}) \mathbf{A}$, and $\mathrm{Co}(\mathrm{III}) \mathbf{B}$ at $50^{\circ} \mathrm{C}$

\begin{tabular}{ccccc}
\hline substrate & catalyst & $\mathrm{pH}$ & $k_{\text {cat }}\left(\mathrm{h}^{-1}\right)$ & $K_{\mathrm{m}}\left(10^{-4} \mathrm{M}\right)$ \\
\hline \multirow{2}{*}{ Alb } & Co(III)A & 9.5 & $0.62 \pm 0.06$ & $7.2 \pm 1.4$ \\
& Co(III)B & 9.5 & $0.016 \pm 0.001$ & $0.47 \pm 0.14$ \\
\multirow{2}{*}{ Glo } & Co(III)A & 9.5 & $0.50 \pm 0.06$ & $7.3 \pm 1.7$ \\
& Co(III)B & 9.5 & $0.014 \pm 0.001$ & $0.64 \pm 0.10$ \\
\multirow{2}{*}{ Myo } & Co(III)A & 8.0 & $0.40 \pm 0.02$ & $4.8 \pm 0.6$ \\
& Co(III)B & 8.0 & $0.019 \pm 0.002$ & $0.84 \pm 0.11$ \\
\multirow{2}{*}{ Lys } & Co(III)A & 9.5 & $0.88 \pm 0.11$ & $9.0 \pm 3.0$ \\
& Co(III)B & 9.5 & $0.27 \pm 0.15$ & $37 \pm 22$ \\
\hline
\end{tabular}



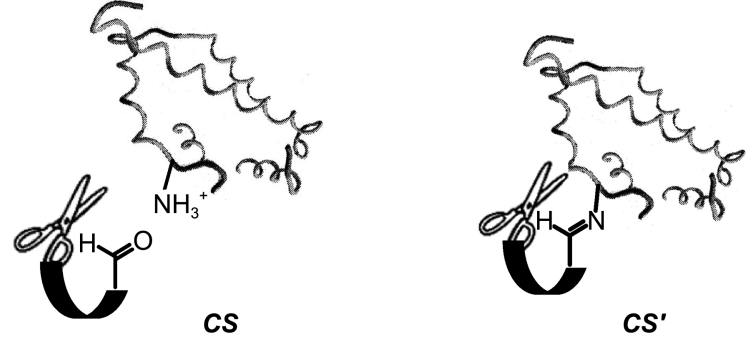

Table 2. Effect of $\mathrm{Na}(\mathrm{CN}) \mathrm{BH}_{3}$ on the rate constant in cleavage of $3.0 \mu \mathrm{M}$ albumin by $1.0 \mathrm{mM} \operatorname{Co}(\mathrm{III}) \mathbf{A}$ and $\mathrm{Co}(\mathrm{III}) \mathbf{B}$ at $\mathrm{pH} 6.0$ and $50{ }^{\circ} \mathrm{C}$

\begin{tabular}{ccc}
\hline catalyst & {$\left[\mathrm{Na}(\mathrm{CN}) \mathrm{BH}_{3}\right](\mathrm{mM})$} & $k_{0}\left(\mathrm{~h}^{-1}\right)$ \\
\hline \multirow{2}{*}{$\mathrm{Co}(\mathrm{III}) \mathbf{A}$} & 0 & $0.030 \pm 0.003$ \\
& 5.0 & $0.42 \pm 0.03$ \\
$\mathrm{Co}(\mathrm{III}) \mathbf{B}$ & 0 & $0.0097 \pm 0.0023$ \\
& 5.0 & $0.0095 \pm 0.0021$ \\
\hline
\end{tabular}

hanced by incorporation of the aldehyde group in proximity at all of the $C_{0}$ concentrations examined. This may be attributed to the reversible formation of the imine bond between the aldehyde group of the catalyst and the ammonium group of the substrate in the catalyst-substrate complex (CS), leading to the formation of the covalent intermediate $\left(C S^{\prime}\right)$, as proposed in the previous studies. ${ }^{8,13}$

To obtain evidence for the existence of the imine-Co(III)A catalysts, it was attempted to trap the imine with $\mathrm{Na}(\mathrm{CN}) \mathrm{BH}_{3}$, the reducing agent selective for imines in water, ${ }^{13,18}$ and the results are summarized in Table 2. If the imine bond is reduced to the amine bond, reverse reaction of $C S$ ' to form $C S$ is blocked, leading to rate enhancement for cleavage of the protein substrate. ${ }^{13}$ The results summarized in Table 2 indicate that $\mathrm{Na}(\mathrm{CN}) \mathrm{BH}_{3}$ raises the proteolytic rate of $\mathrm{Co}(\mathrm{III}) \mathrm{A}$ without affecting the rate for $\mathrm{Co}(\mathrm{III}) \mathrm{B}$. The results obtained with $\mathrm{Na}$ $(\mathrm{CN}) \mathrm{BH}_{3}$ support the existence of an imine intermediate in the proteolytic action of $\mathrm{Co}(\mathrm{III}) \mathrm{A}$.

Examination of the results summarized in Table 1 discloses that the faster rates of $\mathrm{Co}(\mathrm{III}) \mathbf{A}$ compared with $\mathrm{Co}(\mathrm{III}) \mathbf{B}$ originate from the greater values of $k_{\text {cat }}$. The values of $K_{\mathrm{m}}$ are, however, more favorable for Co(III)B except for Lys. The Michaelis-Menten scheme of eq. 1 can be modified as eq. 5 to include $C S$. The same saturation kinetic behavior (eqs. 2 and 6) is predicted for the dependence of $k_{0}$ on $C_{0}$ by both eq. 1 and eq. 5. By applying the steady-state approximation to $C S$ and $C S^{\prime}$, eqs. 7 and 8 are derived. Here, $[C S]$ and $\left[C S^{\prime}\right]$ are the steady state concentrations of $C S$ and $C S^{\prime}$, respectively.

$$
\begin{aligned}
& C+S \underset{k_{-1}}{\stackrel{k_{1}}{\rightleftarrows}} C S \underset{k_{-2}}{\stackrel{k_{2}}{\rightleftarrows}} C S \stackrel{k_{3}}{\longrightarrow} C+P_{1}+P_{2} \\
& k_{\mathrm{o}}=k_{\mathrm{cat}}{ }^{\text {app }} C_{0} /\left(K_{\mathrm{m}}{ }^{\text {app }}+C_{0}\right) \\
& k_{\text {cat }}^{\text {app }}=k_{2} k_{3} /\left(k_{2}+k_{-2}+k_{3}\right)=k_{3} /\left(1+[C S] /\left[C S^{\prime}\right]\right) \\
& K_{\mathrm{m}}^{\mathrm{app}}=\left(k_{2} k_{3}+k_{-1} k_{3}+k_{-1} \mathrm{k}_{-2}\right) / k_{1}\left(k_{2}+k_{-2}+k_{3}\right) \\
& =[C][S] /\left([C S]+\left[C S^{\prime}\right]\right)
\end{aligned}
$$

The higher values of $k_{\text {cat }}$ (or $k_{\text {cat }}^{\text {app }}$ ) of Co(III)A compared with those of Co(III)B (Table 1) are consistent with the higher effective molarity of the catalytic center toward the scissile peptide bond in $C S$ ' owing to more favorable entropic factor. Eq. 7 indicates that the limiting value of $k_{\mathrm{cat}}$ app is $k_{3}$, the first-order rate constant for the reaction of the $\mathrm{Co}$ (III) center with the scissile bond in $C S^{\prime}$. If [CS'] is smaller than [CS], however, $k_{\text {cat }}^{\text {app }}$ is smaller than $k_{3}$, reducing the catalytic efficiency at high $C_{0}$ concentrations.

The higher values of $K_{\mathrm{m}}$ (or $K_{\mathrm{m}}{ }^{\text {app }}$ ) of Co(III)A compared with those of $\mathrm{Co}(\mathrm{III}) \mathrm{B}$ (Table 1) indicate that the sum of $[C S]$ and $\left[C S^{\prime}\right]$ for $\mathrm{Co}(\mathrm{III}) \mathbf{A}$ is smaller than $[C S]$ for $\mathrm{Co}(\mathrm{III}) \mathbf{B}$ when the same values of $C_{0}$ are used. This reveals that $C S^{\prime}$ does not accumulate in a significant amount.

The data reported in the previously study for the $\mathrm{Cu}(\mathrm{II})$ complex of $\mathbf{A}(\mathbf{C u}(\mathrm{II}) \mathbf{A})$ and the $\mathrm{Cu}(\mathrm{II})$ complex of $\mathbf{B}$ $(\mathrm{Cu}(\mathrm{II}) \mathbf{B})$ showed that $k_{\text {cat }}$ is raised and $K_{\mathrm{m}}$ is lowered, leading to the improvement in both $k_{\text {cat }}$ and $K_{\mathrm{m}}$ upon introduction of the aldehyde group in the vicinity of the $\mathrm{Cu}$ (II) center. In the action of $\mathrm{Cu}(\mathrm{II}) \mathbf{A}, C S^{\prime}$ appears to accumulate in a significant amount in contrast with Co(III)A. The values of $k_{\text {cat }}$ and $K_{\mathrm{m}}$ for the action of $\mathrm{Cu}(\mathrm{II}) \mathrm{A}$ for the proteins listed in Table 1 were $0.2-0.8 \mathrm{~h}^{-1}$ and $0.5-5 \mathrm{mM}$, respectively. Although the values of $K_{\mathrm{m}}$ were more favorable for $\mathrm{Cu}(\mathrm{II}) \mathrm{A}$ compared with $\mathrm{Co}(\mathrm{III}) \mathbf{A}$, similar values of $k_{\text {cat }}$ were obtained for $\mathrm{Cu}(\mathrm{II}) \mathbf{A}$ and $\mathrm{Co}$ (III)A.

In conclusion, the proteolytic activity of $\mathrm{Co}(\mathrm{III})$ oxacyclen was considerably improved by conjugation with the aldehyde group owing to formation of covalent intermediates with protein substrates. The proteolytic activity of $\mathrm{Co}(\mathrm{III})$ oxacyclenaldehyde conjugate was comparable to that of $\mathrm{Cu}(\mathrm{II})$ oxacyclenaldehyde conjugate. The $\mathrm{Co}(\mathrm{III})$-based homogeneous artificial proteases would have advantages compared with the $\mathrm{Cu}(\mathrm{II})$ analogues due to the exchange inertness of the metal center.

\section{Experimental Section}

Synthesis of $\mathbf{A}$ and $\mathbf{B}$ was described in the literature. ${ }^{13}$ The $\mathrm{Co}(\mathrm{III})$ complexes of $\mathbf{A}$ and $\mathbf{B}$ were prepared according to the method reported previously. ${ }^{7,-11,15}$ The substrate proteins were obtained from Sigma. Rate measurements carried out as reported previously. ${ }^{13}$

Acknowledgments. This work was supported by National Research Foundation of Korea (NRF) grant funded by the Korea government (MEST) (No. 2009-0072151).

\section{References}

1. Rao, M. B.; Tanksale, A. P.; Ghatge, M. S.; Deshpande, V. V. Microbiol. Mol. Biol. Rev. 1998, 62, 597-635.

2. Suh, J. Acc. Chem. Res. 2003, 36, 562-570.

3. Jang, B.-B.; Lee, K.-P.; Min, D.-H.; Suh, J. J. Am. Chem. Soc. 1998, 120, 12008-12016.

4. Jeon, J. W.; Son, S. J.; Yoo, C. E.; Hong, I. S.; Song, J. B.; Suh, J. Org. Lett. 2002, 4, 4155 - 4158.

5. Jeon, J. W.; Son, S. J.; Yoo, C. E.; Hong, I. S.; Suh, J. Bioorg. Med. Chem. 2003, 11, 2901-2910.

6. Yoo, C. E.; Chae, P. S.; Kim, J. E.; Jeong, E. J.; Suh, J. J. Am. Chem. Soc. 2003, 125, 14580-14589. 
7. Chae, P. S.; Kim, M.-s.; Jeung, C.-S.; Lee, S. D.; Park, H.; Lee, S. Y.; Suh, J. J. Am. Chem. Soc. 2005, 127, 2396-2397.

8. Yoo, S. H.; Lee, B. J.; Kim, H.; Suh, J. J. Am. Chem. Soc. 2005, $127,9593-9602$.

9. Suh, J.; Yoo, S. H.; Kim, M. G.; Jeong, K.; Ahn, J. Y.; Kim, M.-s.; Chae, P. S.; Lee, T. Y.; Lee, J.; Lee, J.; Jang, Y. A.; Ko, E. H. Angew. Chem. Intl. Ed. Engl. 2007, 46, 7064-7067.

10. Suh, J.; Chei, W. S.; Lee, T. Y.; Kim, M. G.; Yoo, S. H.; Jeong, K.; Ahn, J. Y. J. Biol. Inorg. Chem. 2008, 13, 693-701.

11. Lee, J.; Yoo, S. H.; Jeong, K.; Lee, T. Y.; Ahn, J. Y.; Suh, J. Bull. Korean Chem. Soc. 2008, 29, 882-884.

12. Jang, S. W.; Suh, J. Org. Lett. 2008, 10, 481-484.
13. Kim, M. G.; Yoo, S. H.; Chei, W. S.; Lee, T. Y.; Kim, H. M.; Suh, J. J. Biol. Inorg. Chem. 2010, 15, 1023-1031.

14. Greenwood, N. N.; Earnshaw, A. In Chemistry of the Elements, 2nd ed.; Butterworth-Heinemann: Oxford, 1997; p 1123.

15. Kim, H. M.; Jang, B.; Cheon, Y. E.; Suh, M. P., Suh, J. J. Biol. Inorg. Chem. 2009, 14, 151-157.

16. Bodwell, C. E.; McClain, P. E. In The Science of Meat and Meat Products, 2nd ed.; Price, J. F., Schweigert, B. S., Eds.; W. H. Freeman: San Francisco, 1971; p 97.

17. Lameli, U. K. Nature 1970, 227, 680-685.

18. Borch, R. F.; Bernstein, M. D.; Durst, H. D. J. Am. Chem. Soc. 1971, 93, 2897-2904. 